\title{
Utilization of Carob (Ceratonia siliqua L.) Extract as Functional Ingredient in Some Confectionery Products
}

\author{
Rehab Mohamed Ibrahim ${ }^{1 *}$, Faten Farouk Abdel-Salam², Elsayed Farahat ${ }^{1}$ \\ ${ }^{1}$ Department of Special Food and Nutrition, Food Technology Research Institute, Agricultural Research Center, Giza, Egypt \\ ${ }^{2}$ Department of Food Science and Technology, Faculty of Agriculture (El-Shatby-21545), Alexandria University, Alexandria, Egypt \\ Email: ${ }^{\star}$ rehabmohamed_eg@yahoo.com
}

How to cite this paper: Ibrahim, R.M., Abdel-Salam, F.F. and Farahat, E. (2020) Utilization of Carob (Ceratonia siliqua L.) Extract as Functional Ingredient in Some Confectionery Products. Food and Nutrition Sciences, 11, 757-772.

https://doi.org/10.4236/fns.2020.118054

Received: July 8, 2020

Accepted: August 3, 2020

Published: August 6, 2020

Copyright $\odot 2020$ by author(s) and Scientific Research Publishing Inc. This work is licensed under the Creative Commons Attribution-NonCommercial International License (CC BY-NC 4.0).

http://creativecommons.org/licenses/by-nc/4.0/

\begin{abstract}
The aim of this study was to investigate the physicochemical and antioxidant activity of carob pod powder and its use in preparing of functional drinks, and some confectionery products. The raw and heated $\left(\right.$ at $110^{\circ} \mathrm{C}$ and $130^{\circ} \mathrm{C} / 20 \mathrm{~min}$ ) carob powder was used in preparing of drinks. The concentrate carob drink was used in preparing of some confectionery products. The drying process significantly decreased the moisture and total sugars values in carob powder. The antioxidant activity (was measured by two different assays, which are DPPH radical scavenging activity and FRAP) of heated carob powder drinks was lower than the raw carob powder drink, while total phenolic not affected. The best sensory acceptability was observed with raw carob powder drink at ratio 1:2 (carob powder: water). The concentration process caused significant increase in total phenolic and antioxidant activity of carob drink. According to the sensory evaluation results, the carob concentrate was used in preparation of Toffee, Jelly candy and Turkish delight by 5\%, 20\% and $10 \%$, respectively. The carob concentrate increased the antioxidant activity of the previous confectionery products. From these results the carob concentrate could be used in preparation of functional and healthy foods.
\end{abstract}

\section{Keywords}

Carob (Ceratonia siliqua L.), Candy Products, Antioxidant Activity, Healthy Food

\section{Introduction}

Carob (Ceratonia siliqua L.) tree belongs to family Leguminosae. It has been widely cultivated in the Mediterranean region [1] [2]. Its fruit is a pod contain- 
ing $10 \%$ - 20\% seeds [3] [4]. Pods consist of 50\% - 65\% sugars (sucrose, glucose, fructose and maltose), $1 \%-5 \%$ proteins, $0.2 \%-0.8 \%$ lipids , $11 \%-16 \%$ crude fibers (mainly, cellulose and hemicellulose), 1\% - 6\% minerals [5] [6], mostly calcium, potassium, magnesium, sodium, phosphorus, copper, zinc and iron) [7] [8], vitamins (E, D, C, Niacin, B6 and folic acid) [8], considerable amounts of dietary fibers and polyphenols (condensed tannins and proanthocyanidens) [8] [9].

The natural polyphenols in carob pods exhibit a wide range of biological properties. They have strong antioxidant activity against developed free radicals during oxidation in living organisms as well as in food and food products, and the ability to inhibit the oxidative damage of some important biomolecules (DNA, protein, and lipids). The presence of polyphenols helps in using carob in preparing healthy food products by increasing their level of such compounds and therefore protects from the occurrence of degenerative diseases such as cancer, inflammatory, cardiovascular, and neurodegenerative diseases [10].

According to Roseiro et al. [11], Pods and seeds of carob fruit can be used as raw material in food, pharmaceutical, and cosmetics industries. In the food industry, they are used in preparing gum, sugars, alcohol, and as a natural additive (E 410) [2].

Because carob pods contain a high level of sugars (mostly $75 \%$ or more of sucrose) it was used as a natural sweetener [12], a raw material for syrup production, crystallized sucrose production, wine, pharmaceutical industry, carob honey in cakes and pastries, sweetener for compote and jam [13]. Also due to its sweetness, flavor similar to chocolate and its low price, the seedless pod's powder is widely used in the Mediterranean region as a cocoa substitute for sweets, biscuits, confectionery products, bakery goods and drinks production [2] [5]. One of the advantages of using carob powder as a cocoa substitute, it is free from caffeine and theobromine [2] [14] [15].

Water extract of carob powder contains sugars, soluble dietary fibers, water-soluble tannins, flavanol glycosides, and gallic acid [16]. It has a strong antioxidant activity and therefore can use as a functional ingredient in food development [17]. Rtibi et al. [18] showed that carob pods water extract has an antioxidant, anti-diarrheal, anti-bacterial, anti-diabetic, hypoglycemic, anti-absorptive of glucose effects, anti-inflammatory and antiulcer effects. Custodio et al. [19] attributed such pharmacological actions to its antioxidant activity, which scavenges free radicals and/or inhibits lipid peroxidation.

Carob is mainly used in Arab countries to prepare a drink and partially some types of confectioneries. In western countries, carob powder is prepared by deseeding pods to yield kibbled carob, then heating, milling, sieving, and packaging. These powders can be used to prepare carob juice concentrate [20].

This study was carried out to use seedless carob pods powder flour as a functional ingredient in preparing a healthy drink, concentrate, and some confectionery products. The proximate composition, minerals content, dry heating con- 
ditions, sensory properties, total polyphenols, and antioxidant activity of carob concentrate, drink, and some confectionery products were investigated in this study.

\section{Materials and Methods}

\subsection{Materials}

Five kilograms of carob pods were purchased from Aswan Governorate, Egypt, in October 2017. Sucrose, glucose syrup, butter (82\% fat), concentrated milk, corn starch, edible gelatin, palm oil, common salt, soybean lecithin, plain cellophane and glass bottles were purchased from local market of Alexandria, Egypt.

All chemicals used in this study were analytical grade except Folin-Ciocalteu's phenol reagent of Sigma-Aldrich Company (St. Louis, Missouri, USA).

\subsection{Methods}

\subsubsection{Preparation of Carob Pods Powder, Drink and Concentrate}

Method of Dhaouadi et al. [21], was used to clean pods from strange matters, water washing and drying. The seeds were manually separated from pods before milling to pass through sieve ( $40 \mathrm{mesh}$ ). Parts of the resulted pod powder were dry heated for $20 \mathrm{~min}$ at two different temperatures $\left(110^{\circ} \mathrm{C} \& 130^{\circ} \mathrm{C}\right)$. The raw and roasted carob powder were mixed with drinking water at 1:2 and/ or 1:3 w/v ratios and left at $4^{\circ} \mathrm{C}$ for $24 \mathrm{~h}$ then drained. A part of the prepared carob drink water at ratio $1: 2(\mathrm{w} / \mathrm{v})$ and filtered through cloth then concentrated under vacuum at $50^{\circ} \mathrm{C}$ for $48 \mathrm{~h}$ using lab vacuum oven (Model 3618, USA). The obtained concentrate (TSS 79.6\%) was packed in brown glass bottles and stored at $4^{\circ} \mathrm{C}$ until used, according to Dhaouadi et al. [21].

\subsubsection{Preparation of Confectionery Products}

Carob concentrate $(5 \%, 10 \%, 15 \%$ and $20 \%)$ was added to replace parts of added sugar in the formula of the following confectionery products. The following concentrations of:

\section{1) Gummy Jelly Candy}

This product was prepared as described by Garcia [22] using the following ingredients: $8 \%$ edible gelatin, $24.5 \%$ water, $33 \%$ sugar, $31.5 \%$ glucose syrup, and $3 \%$ citric acid solution of $50 \%$ concentration. Carob concentrated, glucose syrup, sugar, and water were mixed, heated in an aluminum pan, gelatin solution (prepared by dissolving gelatin in warm water $\left(70^{\circ} \mathrm{C}\right)$ ) was added with continuous mixing to prevent burning until the temperature of the mixture raised to $116^{\circ} \mathrm{C}$, citric acid was added and mixing was continued until Brix value of the mixture was adjusted to $68 \%-75 \%$ [23].

\section{2) Toffee}

Toffee was prepared according to Samsiah et al. [24] with the following formula: $25.1 \%$ sugar, $20.1 \%$ glucose syrup, $25.1 \%$ condensed milk, $14.5 \%$ palm oil, $9.7 \%$ butter, $0.4 \%$ salt, $0.3 \%$ lecithin and $4.8 \%$ water. Processing of the toffee involved mixing, cooking with continuous stirring, the mixture was 
cooked until temperature $110^{\circ} \mathrm{C}$ before adding the butter, cooling, tempering, rolling in plain cellophane, cutting, and wrapping. Cooking was continued to $124^{\circ} \mathrm{C}$, then pouring onto an oiled marble slab, cooled, and wrapped.

\section{3) Turkish Delight}

Turkish delight was prepared according to Samsiah et al. [24] using the following formula: Starch (6.9\%), sucrose (41\%), glucose syrup (11\%), gelatin $(0.1 \%)$, and water $(41 \%)$. The preparation of this product involved mixing the gelatin solution (prepared by dissolving gelatin in $70^{\circ} \mathrm{C}$ warm water) with other ingredients and boiling for $2 \mathrm{~min}$, cooking with constant stirring continued to $110^{\circ} \mathrm{C}-112^{\circ} \mathrm{C}$ until the total soluble solids reached $75^{\circ}$ Brix, cooling, cutting, and wrapping.

\subsubsection{Physicochemical Analysis}

Moisture, fat, protein and ash of carob powder were determined as described in AOAC [25]. Ashed carob was digested in $10 \mathrm{ml} \mathrm{mol} / \mathrm{L} \mathrm{HCl}$ and $\mathrm{Ca}, \mathrm{Fe}, \mathrm{Mn}$, and $\mathrm{Zn}$ were measured by atomic absorption spectrometry (AA680, Shimadzu, Japan) [25]. The following analytical tests were carried out in triplicates as described in AOAC [25], total soluble solids (TSS) using the hand Atago Refractometer at $25^{\circ} \mathrm{C}$, titratable acidity (TA) as citric acid (\%) by the titration of homogenized drinks with $0.1 \mathrm{M} \mathrm{NaOH}$ to an end point of $\mathrm{pH} 8.2, \mathrm{pH}$ value using a digital Metler Toledo Mp $230 \mathrm{pH}$ meter, reducing and total sugars by the Lane-Eynon method after hydrolyzing non reducing sugars with $2.5 \mathrm{~N} \mathrm{HCL}$ for $3 \mathrm{~h} / 70^{\circ} \mathrm{C}$ and non-reducing sugars was calculated by the difference between reducing sugars content after and before hydrolysis of the total sugars.

\subsubsection{Total Phenolic (TP) Content}

TP was assayed by Folin-Ciocalteu's reagent using gallic acid as a standard at a wave length of $765 \mathrm{~nm}$ using UV-Vis. Spectrophotometer (Laxco-Alpha-1102, Suite, USA) [26].

\subsubsection{Antioxidant Activity}

Antioxidant capacity assays are beneficial to evaluate the overall antioxidant activity in foods. In the current study, the antioxidant activity of carob drink, carob concentrate and confectionery products water-soluble extracts was measured by two different assays, which are DPPH radical scavenging activity and ferric reducing antioxidant power (FRAP).The scavenging activity of the stable 1,1-diphenyl-2-picrylhydrazyl (DPPH) radical according to a procedure based on Brand-Williams et al. [27]; Miliauskas et al. [28] and it's a modification by Lim and Quah [29] at a wave length of $517 \mathrm{~nm}$ using a spectrophotometer (Pg T80, England) and Ascorbic acid was used as a standard and the results were expressed as \% radical scavenging activity [30].

$$
\text { Radical scavenging activity } \%=\frac{(\text { Acontrol }- \text { Asample })}{\text { Acontrol }} \times 100
$$

The second method was ferric reducing antioxidant power (FRAP): This pro- 
posed by Pulido et al. [31]. It based on the reduction of the ferricyanide complex to the ferrous form was followed at $700 \mathrm{~nm}$ using a spectrophotometer (Pg T80+, England). Triplicate tubes were prepared for each extract. The FRAP values, expressed in $\mathrm{mg} \mathrm{GAE/g}$, were derived from a standard curve.

\subsubsection{Sensory Evaluation}

Sensory evaluation of the products was done by 14 trained panelists from Food Technology Research Institute, Agricultural Research Center, Alexandria, Egypt.9-point hedonic scale ( $1=$ dislike extremely, $9=$ like extremely) [23].

\subsubsection{Statistical Analysis}

All determinations were performed in triplicate $(n=3)$ and the data were expressed as mean \pm standard deviation (SD). Data were statistically analyzed using statistical analysis system version 8.1 (2000). A difference was considered statistically significant, when $P<0.05$, SAS [32].

\section{Results and Discussion}

\subsection{Raw Carob Powder}

As shown from Table 1, carob powder had low moisture (10.30\%) and crude fat $(0.73 \%)$ contents, the main components affect its storage stability and shelf life. Therefore, it can be stored at room temperature. In addition, it is low in protein content $(3.48 \%)$, and ash $(2.67 \%)$. The main compounds of this product are carbohydrate and fibers. In this study, total sugars represented more than percentage of seedless carob pod powder. It was formed from $27.88 \%$ reducing sugars and $72.12 \%$ non-reducing sugars. Both compounds are responsible of carob sweetness. El Batal et al. [12] showed that more than $70 \%$ of total sugars in carob pods was sucrose. Lafuente [33] suggested the utilization of carob pod as a raw material for crystalled sucrose production.

Data in Table 1 indicate that carob powder contained considerable levels of $\mathrm{Ca}, \mathrm{Fe}, \mathrm{Mn}$ and Zn. Same observation was stated by Ozcan et al. [7], and Youssef et al. [8]. They stated that the main mineral of carob powder ash were $\mathrm{Ca}, \mathrm{K}, \mathrm{Mg}$, $\mathrm{Na}, \mathrm{P}, \mathrm{Cu}, \mathrm{Zn}$ and $\mathrm{Fe}$. It is known that $\mathrm{Ca}$ is an essential element in building muscles, bones and teeth of human especially children and women.

\subsection{Dried Carob Powder}

Seedless carob pod powder was heated for 20 min either at $110^{\circ} \mathrm{C}$ and/or $130^{\circ} \mathrm{C}$. The aim was to enhance flavor and improve color of this product before using in preparing drink and concentrates.

As seen from Figure 1 heating at $110^{\circ} \mathrm{C}$ for 20 min give product light in color with its specific original flavor. In contrast, the heating product at $130^{\circ} \mathrm{C}$ for 20 min had dark color with strong flavor due to the sugar caramelization and Millard reaction of carob powder at this temperature (Figure 1).

Nearly same observations were reported by Boublenza et al. [30] they found that the powder became completely dark when drying at $150^{\circ} \mathrm{C}$ for $20 \mathrm{~min}$ as a 
Table 1. Some chemical components and minerals content of seedless carob powder.

\begin{tabular}{cc}
\hline Component & Value $\left.^{*} \%\right)$ \\
\hline Moisture (\%) & $10.30 \pm 0.45$ \\
Total sugars (\%) & $54.29 \pm 0.81$ \\
Reducing sugars (\%) & $15.14 \pm 0.63$ \\
Non reducing sugars (\%) & $39.15 \pm 0.48$ \\
Dietary fibers (\%) & $21.10 \pm 0.40$ \\
Crude fibers (\%) & $7.43 \pm 0.53$ \\
Protein (N $\times 6.25)(\%)$ & $3.48 \pm 0.83$ \\
Fat (\%) & $0.73 \pm 0.91$ \\
Ash (\%) & $2.67 \pm 0.04$ \\
Calcium (ppm) & 864.0 \\
Iron (ppm) & 66.90 \\
Manganese (ppm) & 12.70 \\
Zinc (ppm) & 21.80 \\
\hline
\end{tabular}

${ }^{*}$ Values are the mean of three replicates $\pm \mathrm{SD}$.

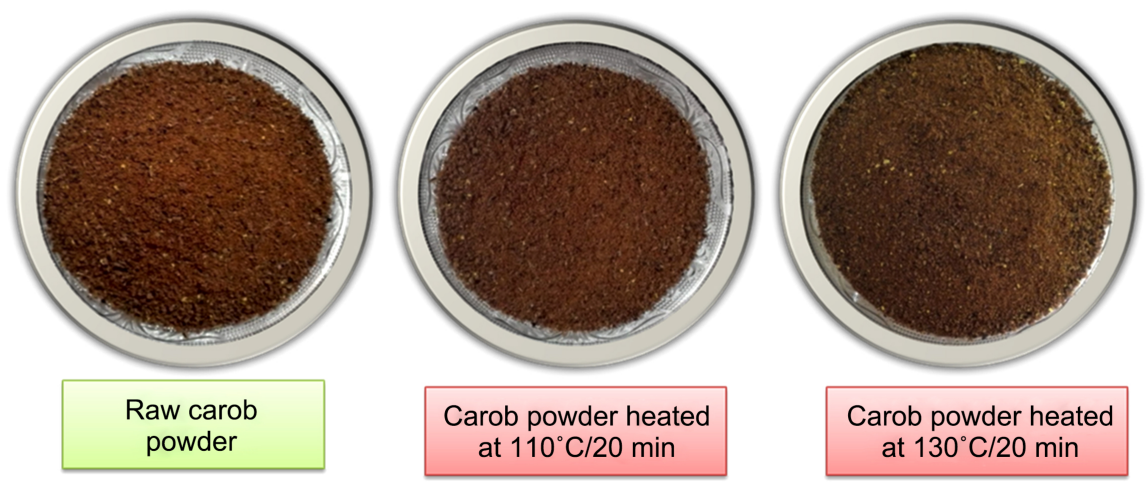

Figure 1. Effect of dry heating at $110^{\circ} \mathrm{C}$ and $130^{\circ} \mathrm{C}$ for $20 \mathrm{~min}$ on the color of carob pods powders.

result of producing brown pigments. Results in Figure 2 show a reduction in moisture content, both reducing and non-reducing sugars after heating. The highest loss was in reducing sugars $22.39 \%$ and $44.05 \%$ followed by moisture $12.33 \%$ and $20.78 \%$, non-reducing sugars $6.33 \%$ and $11.44 \%$ at 110 and $130^{\circ} \mathrm{C}$ respectively. This means that such losses increased with increasing heating temperature. The same conclusion was stated with Boublenza et al. [30] as mentioned above, caramelization and Millard reaction behind sugars loss particularly when dry heating.

\subsection{Carob Drinks}

Different types of carob drinks were prepared from raw and heated (at $110^{\circ} \mathrm{C}$ 


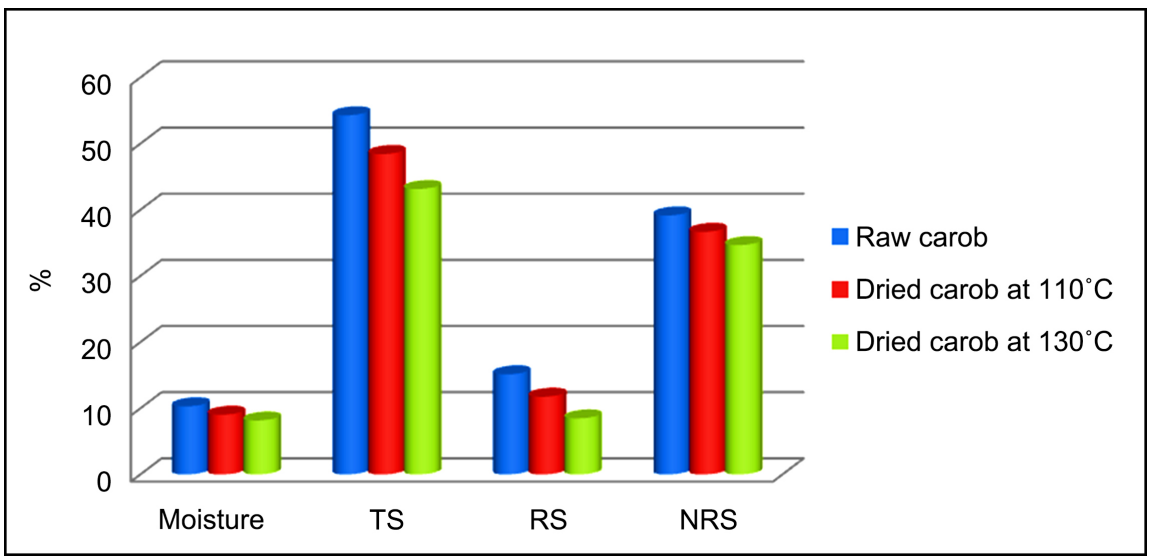

Figure 2. Moisture, total sugars (TS), reducing sugars (RS) and non-reducing sugars (NRS) contents of raw and dried seedless carob pods powder.

and $130^{\circ} \mathrm{C}$ ) carob powders. The results of the determined physicochemical and sensorial properties of such drinks were presented in Table 2. There were significant variations in TSS of carob drinks which due to drying temperatures and dilution ratios were observed. Drinks made by ratio 1:2 (w/v) carob:water, had higher TSS than that prepared from the another dilution ratio. The results of $\mathrm{pH}$ and acidity values of carob drinks prepared from heated carob powder $\left(\right.$ at $110^{\circ} \mathrm{C}$ and $\left.130^{\circ} \mathrm{C}\right)$, showed that, there were no significant $(\mathrm{p}>0.05)$ changes due to the difference in dilution ratio (1:2 and 1:3). While, the $\mathrm{pH}$ and acidity values of carob drinks prepared from raw carob powder were significant $(\mathrm{p}<0.05)$ changed with the change in dilution ratio (1:2 and 1:3). In contrast, increasing drying temperature of carob powder associated with a significant increase in $\mathrm{pH}$ and reduction in TA with each dilution ratios. This maybe due to both caramelization and Millard reactions between carob components during drying process at high temperature. According to Boublenza et al. [30] Millard reaction requires temperature up to $50^{\circ} \mathrm{C}$ and $\mathrm{pH}$ from 4 to 7 . While caramelization of sugars needs temperature higher than $100^{\circ} \mathrm{C}$ and $\mathrm{pH}$ from 3 to 9. Sahin et al. [34] attributed the changes in carob drink quality to heating process conditions (time and temperature). Important chemical reactions including sugar caramelization and Millard reaction (non-enzymatic browning reaction) occurred during carob powder heating, causing changes in physicochemical properties, total phenolic content and antioxidant activity of its drinks. Results in Table 2 showed that, there were a significant $(\mathrm{p}<0.05)$ decrease in DPPH inhibition\% with the two dilution ratios (1:2 and 1:3) of carob drinks prepared from heated carob powder (at $110^{\circ} \mathrm{C}$ and $130^{\circ} \mathrm{C}$ ) compared with drinks from raw carob powder. Concerning to the FRAP values of carob drinks prepared from heated carob powder, there was a significant $(\mathrm{p}<0.05)$ decrease with dilution ratio $1: 2$, while, no significant $(p>0.05)$ differences were noticed with dilution ratio 1:3 compared with raw carob powder drink. On The other hand, no changes were observed in total phenolic content of carob drinks prepared from heated carob compared with raw carob powder drink at the same dilution ratio. 
Table 2. Physicochemical and sensory properties of carob drinks.

\begin{tabular}{|c|c|c|c|c|c|}
\hline \multirow[b]{2}{*}{ Property } & \multirow{2}{*}{$\begin{array}{c}\text { Carob: water } \\
\text { dilution ratio } \\
(w / v)\end{array}$} & \multicolumn{3}{|c|}{ Carob drink from } & \multirow[b]{2}{*}{ Means } \\
\hline & & Raw & $\begin{array}{c}\text { Drying at } \\
110^{\circ} \mathrm{C}\end{array}$ & $\begin{array}{c}\text { Drying at } \\
130^{\circ} \mathrm{C}\end{array}$ & \\
\hline \multicolumn{6}{|c|}{ 1) Physicochemical properties } \\
\hline \multirow{2}{*}{ TSS } & $1: 2$ & $21.76 \pm 0.057^{\mathrm{a}}$ & $21.26 \pm 0.057^{\mathrm{b}}$ & $19.66 \pm 0.000^{c}$ & $20.89^{A}$ \\
\hline & $1: 3$ & $16.16 \pm 0.057^{\mathrm{d}}$ & $15.66 \pm 0.057^{\mathrm{e}}$ & $15.53 \pm 0.057^{\mathrm{e}}$ & $15.78^{B}$ \\
\hline \multicolumn{2}{|c|}{ Means } & $18.96^{\mathrm{A}}$ & $18.46^{\mathrm{B}}$ & $17.60^{\mathrm{C}}$ & \\
\hline \multirow{2}{*}{$\mathrm{pH}$} & $1: 2$ & $5.17 \pm 0.006^{\mathrm{d}}$ & $5.36 \pm 0.000^{\mathrm{b}}$ & $5.43 \pm 0.058^{\mathrm{a}}$ & $5.32^{\mathrm{A}}$ \\
\hline & $1: 3$ & $5.25 \pm 0.029^{c}$ & $5.35 \pm 0.000^{\mathrm{b}}$ & $5.43 \pm 0.000^{\mathrm{a}}$ & $5.34^{\mathrm{A}}$ \\
\hline \multicolumn{2}{|c|}{ Means } & $5.21^{\mathrm{C}}$ & $5.35^{\mathrm{B}}$ & $5.43^{\mathrm{A}}$ & \\
\hline \multirow{2}{*}{$\begin{array}{c}\text { Total acidity } \\
\text { (\%) }\end{array}$} & $1: 2$ & $0.40 \pm 0.010^{\mathrm{a}}$ & $0.34 \pm 0.010^{\mathrm{b}}$ & $0.32 \pm 0.020^{c}$ & $0.35^{\mathrm{A}}$ \\
\hline & $1: 3$ & $0.35 \pm 0.006^{\mathrm{b}}$ & $0.34 \pm 0.017^{\mathrm{b}}$ & $0.32 \pm 0.006^{c}$ & $0.34^{\mathrm{A}}$ \\
\hline \multicolumn{2}{|c|}{ Means } & $0.38^{\mathrm{A}}$ & $0.34^{\mathrm{B}}$ & $0.32^{\mathrm{C}}$ & \\
\hline \multirow{2}{*}{$\begin{array}{l}\text { Total phenolic } \\
\qquad(m g G A / g)\end{array}$} & $1: 2$ & $4.32 \pm 0.065^{\mathrm{ab}}$ & $4.38 \pm 0.06^{\mathrm{a}}$ & $4.41 \pm 0.051^{\mathrm{a}}$ & $4.37^{\mathrm{A}}$ \\
\hline & $1: 3$ & $4.21 \pm 0.045^{\mathrm{b}}$ & $4.22 \pm 0.075^{\mathrm{b}}$ & $4.23 \pm 0.065^{\mathrm{b}}$ & $4.22^{\mathrm{B}}$ \\
\hline \multicolumn{2}{|c|}{ Means } & $4.27^{\mathrm{A}}$ & $4.30^{\mathrm{A}}$ & $4.32^{\mathrm{A}}$ & \\
\hline \multirow{2}{*}{ DPPH (\%) } & $1: 2$ & $89.0 \pm 0.092^{\mathrm{a}}$ & $88.2 \pm 0.20^{\mathrm{ab}}$ & $87.4 \pm 0.185^{\mathrm{b}}$ & $88.2^{\mathrm{A}}$ \\
\hline & $1: 3$ & $86.2 \pm 0.021^{\mathrm{bc}}$ & $86.0 \pm 0.103^{c}$ & $86.0 \pm 0.110^{c}$ & $86.1^{\mathrm{B}}$ \\
\hline \multicolumn{2}{|c|}{ Means } & $87.6^{\mathrm{A}}$ & $87.1^{\mathrm{A}}$ & $86.7^{\mathrm{B}}$ & \\
\hline \multirow{2}{*}{$\begin{array}{c}\text { FRAP } \\
(m g G A / g)\end{array}$} & $1: 2$ & $1.28 \pm 0.0043^{\mathrm{a}}$ & $1.22 \pm 0.005^{\mathrm{ab}}$ & $1.19 \pm 0.0046^{\mathrm{b}}$ & $1.23^{\mathrm{A}}$ \\
\hline & $1: 3$ & $1.10 \pm 0.0038^{c}$ & $1.09 \pm 0.0014^{c}$ & $1.06 \pm 0.0060^{c}$ & $1.08^{\mathrm{B}}$ \\
\hline \multicolumn{2}{|c|}{ Means } & $1.19^{\mathrm{A}}$ & $1.16^{\mathrm{A}}$ & $1.13^{\mathrm{B}}$ & \\
\hline \multicolumn{6}{|c|}{ 2) Sensory properties } \\
\hline \multirow{2}{*}{ Color } & $1: 2$ & $8.57 \pm 0.646^{\mathrm{a}}$ & $8.36 \pm 0.745^{\mathrm{ab}}$ & $8.07 \pm 0.829^{b c}$ & $8.33^{\mathrm{A}}$ \\
\hline & $1: 3$ & $7.86 \pm 0.535^{c}$ & $8.14 \pm 0.535^{\mathrm{abc}}$ & $7.93 \pm 0.829^{b c}$ & $7.98^{\mathrm{B}}$ \\
\hline \multicolumn{2}{|c|}{ Means } & $8.22^{\mathrm{A}}$ & $8.25^{\mathrm{A}}$ & $8.0^{\mathrm{A}}$ & \\
\hline \multirow{2}{*}{ Taste } & $1: 2$ & $8.86 \pm 0.363^{\mathrm{a}}$ & $8.43 \pm 1.089^{\mathrm{a}}$ & $7.79 \pm 1.05^{\mathrm{b}}$ & $8.36^{\mathrm{A}}$ \\
\hline & $1: 3$ & $7.71 \pm 1.069^{\mathrm{b}}$ & $7.50 \pm 1.454^{\mathrm{b}}$ & $7.29 \pm 1.59^{\mathrm{b}}$ & $7.50^{\mathrm{B}}$ \\
\hline \multicolumn{2}{|c|}{ Means } & $8.29^{\mathrm{A}}$ & $7.97^{\mathrm{AB}}$ & $7.54^{\mathrm{B}}$ & \\
\hline \multirow{2}{*}{ Odor } & $1: 2$ & $8.21 \pm 1.122^{\mathrm{a}}$ & $8.07 \pm 0.829^{\mathrm{ab}}$ & $7.43 \pm 0.938^{\mathrm{b}}$ & $7.90^{\mathrm{A}}$ \\
\hline & $1: 3$ & $7.64 \pm 0.929^{\mathrm{ab}}$ & $7.79 \pm 0.802^{\mathrm{ab}}$ & $7.57 \pm 1.4^{\mathrm{ab}}$ & $7.67^{\mathrm{A}}$ \\
\hline \multicolumn{2}{|c|}{ Means } & $7.93^{\mathrm{A}}$ & $7.93^{\mathrm{A}}$ & $7.50^{\mathrm{A}}$ & \\
\hline \multirow{2}{*}{$\begin{array}{c}\text { Overall } \\
\text { acceptability }\end{array}$} & $1: 2$ & $8.57 \pm 0.514^{\mathrm{a}}$ & $8.29 \pm 0.726^{\mathrm{ab}}$ & $7.71 \pm 0.726^{c}$ & $8.19^{\mathrm{A}}$ \\
\hline & $1: 3$ & $7.64 \pm 0.842^{\mathrm{c}}$ & $7.79 \pm 0.802^{\mathrm{bc}}$ & $7.36 \pm 1.28^{c}$ & $7.60^{\mathrm{B}}$ \\
\hline \multicolumn{2}{|c|}{ Means } & $8.11^{\mathrm{A}}$ & $8.04^{\mathrm{A}}$ & $7.54^{\mathrm{A}}$ & \\
\hline
\end{tabular}

Different letters in rows indicate significant different value at $\mathrm{p}<0.05$. Values are mean $\pm S D(n=3)$. DPPH: 1,1-diphenyl-2-picrylhydrazyl, FRAP: Ferric reducing antioxidant power. 
Sahin et al. [34], and Čepo et al. [16] stated that, to obtain carob powder with high antioxidant activity, it should be heating at $130^{\circ} \mathrm{C}$ at least for $30 \mathrm{~min}$. During heating, the increased in total phenolic content due to the thermal hydrolysis of tannins and proanthocyanid, and release of high concentrations of free gallic acid [16] [35]. Sahin et al. [34] mentioned that the Maillard reaction and caramelization products such as hydroxyl on ethyl furfural and melanoidins enhance antioxidant activity of carob powder.

Estimation the sensory properties of the prepared carob drinks in this study, Table 2, reveal that except odor, the panelists were significantly $(\mathrm{p}<0.05)$ preferred the color, taste and overall acceptability of the carob drinks prepared with dilution ratio 1:2 than 1:3 (carob: water $(\mathrm{w} / \mathrm{v})$ ). In contrast, no differences in such properties due to drying temperature were recorded.

\subsection{Carob Concentrate}

As mentioned in materials and methods section, carob concentrate with $79.6 \%$ TSS was prepared from the 1:2 w/v (raw carob powder) carob drinks by heating under vacuum at $50^{\circ} \mathrm{C}$ to use as a sucrose replacer, polyphenols as a natural antioxidant and to rise the antioxidant activity of the confectionery products. This concentrate should keep far from oxidation at cold temperature. The total phenolic content and antioxidant activity of concentrate sample (diluted 1:100 with distilled water $(\mathrm{w} / \mathrm{v}))$ were presented in Table 3 . The concentration process caused an increase in total phenolic and antioxidant activity compared to all other drinks. This increase due to the loss of moisture and increase of TSS.

\subsection{Carob Confectionery Products}

The prepared carob concentrate was used to prepare three types of confectionery products by $5 \%, 10 \%, 15 \%$ and $20 \%$ to replace parts of added sugar, and as source of polyphenols to improve the antioxidant activity of such products. Comparing with carob powder, the concentrate is free from suspended particles

Table 3. Some chemical properties and antioxidant activity of carob concentrate.

\begin{tabular}{cc}
\hline Property & Carob concentrate \\
\hline TSS (\%) & $79.6 \pm 0.06$ \\
Total sugars (\%) & $32 \pm 0.82$ \\
Reducing sugars (\%) & $8.16 \pm 0.63$ \\
Non-reducing sugars (\%) & $23.84 \pm 0.57$ \\
Total phenolic content (mg GA/g) & $31.49 \pm 0.164$ \\
DPPH inhibition activity (\%)* & $75.23 \pm 2.477$ \\
FRAP $(\mathrm{mg} \mathrm{GA} / \mathrm{g})^{* *}$ & $0.963 \pm 0.0123$ \\
\hline
\end{tabular}

Values are mean $\pm \mathrm{SD}(\mathrm{n}=3) .{ }^{\star}$ DPPH: 1,1-diphenyl-2-picrylhydrazyl; ${ }^{* *}$ FRAP: Ferric reducing antioxidant power. The antioxidant activities were carryout to diluted concentrate samples (1 g carob concentrate: $100 \mathrm{~g}$ water). 
and only contained water-soluble components, including more polyphenols responsible of the antioxidant activity (Table 3). Papagiannoppulos et al. [36] mentioned that water extract of carob powder contains soluble phenolic compounds such as soluble tannins, flavonol glycosides and Gallic acid. It has a good antioxidant activity [9]. Such activity plays important role in lower the rate of lipid oxidation in life organisms and modulates their blood lipid profile [37].

\subsubsection{Toffee}

According to the panelist's preference, toffee product containing 5\% carob concentrate instead of sucrose in its basic formula was the best and had the very good acceptability. The flavor of this product (taste and odor) was significantly superior to the others toffee products, (Figure 3 ). The other products were also accepted by panelists. Their total acceptability ranged from fair (toffee with $20 \%$ carob concentrate), nearly good (product with $15 \%$ carob concentrate) and very good products (free and with $10 \%$ carob concentrate), (Figure 3 ). The best toffee product (with 5\% carob concentrate) had nearly 15\% moisture, high value of TSS (76.8\%) due to higher content of total sugars (68.53\%), and low total acidity (0.31\%) (Table 4). Reducing sugars represented $63 \%$ of total sugars in this product. As shown from the results in Figure 4, 5\% carob concentrate caused a $6.59,3.8$ and 6.76 times increase in content of toffee from polyphenols, antioxidant activity by DPPH inhibition and FRAP, respectively, than control. This means that such addition improved keeping quality, nutritional value and give healthy product. This product had a soft texture, uniform appearance and light beige color as well as a delicate flavor.

\subsubsection{Jelly Candy}

Panelists did not find any significant differences in sensorial properties between Jelly candy product free and containing different proportions of carob concentrate $(5 \%, 10 \%, 15 \%$ and $20 \%)$. The acceptability of the appearance, color, taste, odor, texture and total acceptability had more than 7 score and a good acceptance (Figure 3). Therefore, the product had 20\% carob concentrate was selected and analyzed to detect some of its physicochemical properties, total phenolic content and antioxidant activity, (Figure 4). Results in Table 4 indicated that this product contained considerable amount of moisture (23.14\%), high value of TSS (70.03\%). This is mostly due to its high total sugar content (69.53\%) and the moderate level of total acidity ( $0.22 \%$ as citric acid). Reducing sugars represented nearly $41 \%$ of total sugars in this product. Using $20 \%$ of carob concentrate also led to rise the total polyphenols content of this product more than 22 times than control.

This also caused increase in the antioxidant activity of such product to more than 5.5 and 9.2 times than control as determined by DPPH and FRAP methods respectively. This means the improving of storage stability, nutritional value and healthy influence of this product. This product had flexible non sticky and elastic texture as well as fragrant flavor and slight cloudy transparency. 


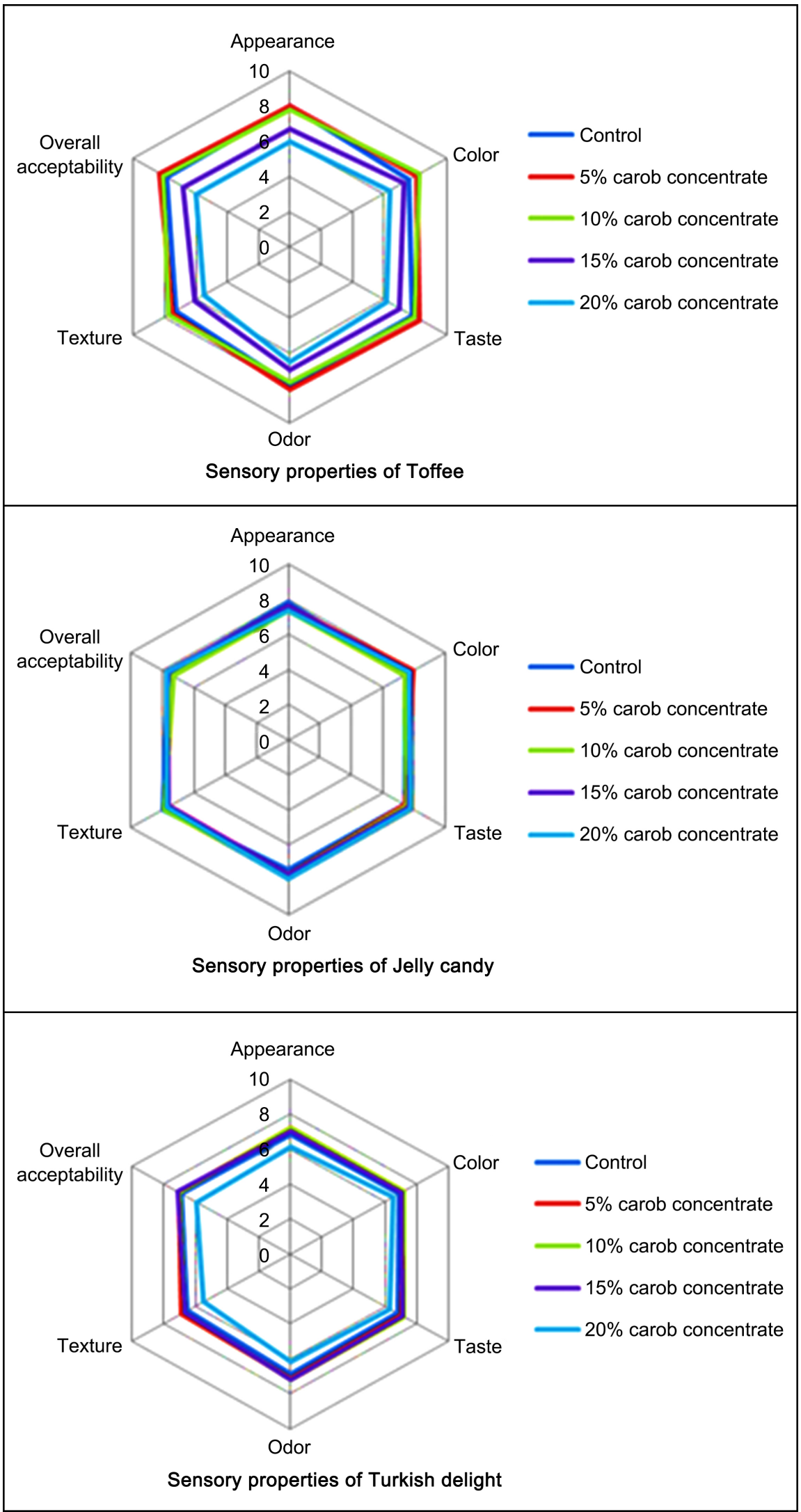

Figure 3. Sensory properties of toffee, jelly candy and Turkish delight containing different carob concentrate additions in their formulation $(\mathrm{N}=14)$. 


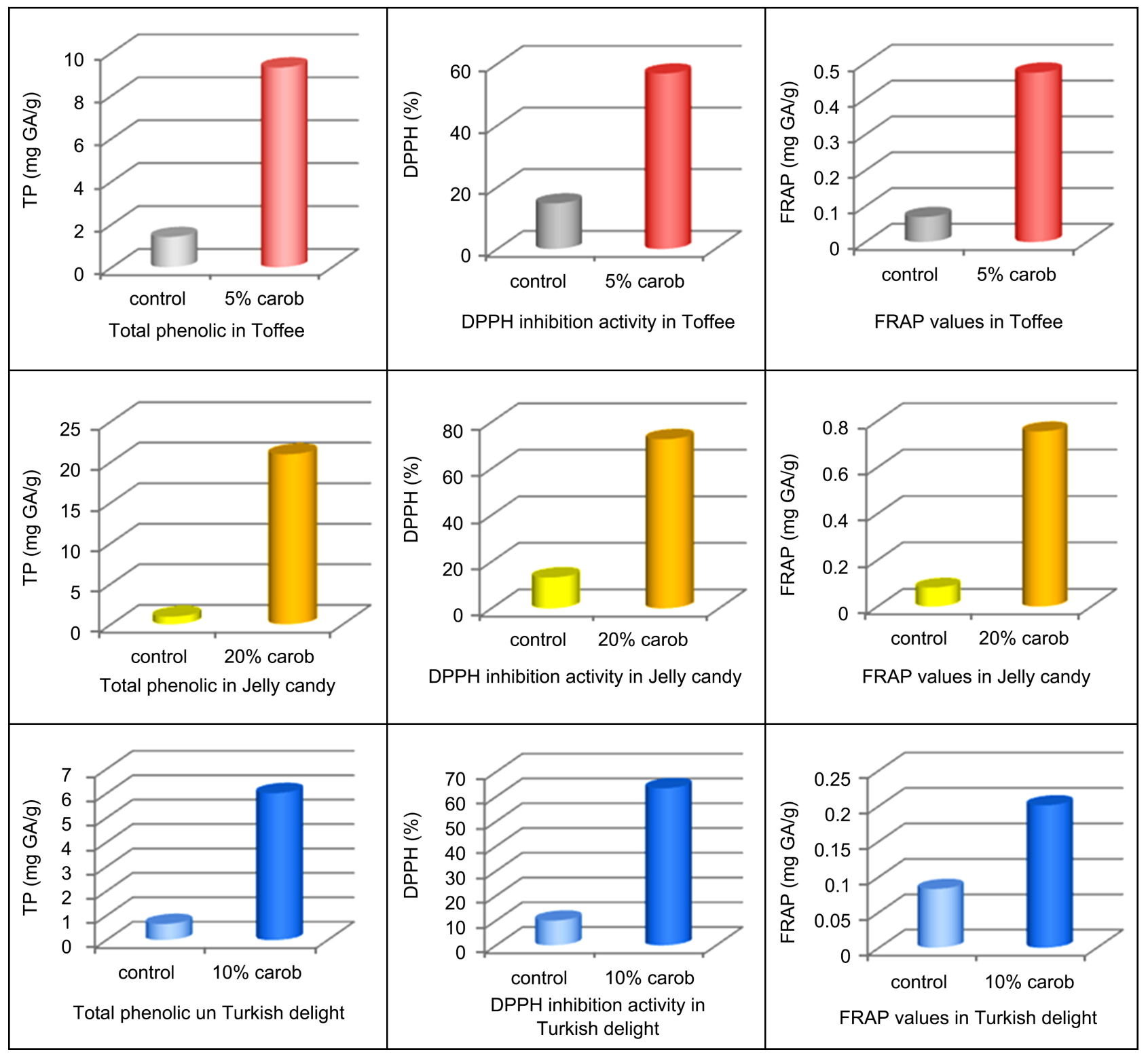

Figure 4. Total phenolic content and antioxidant activity of toffee, jelly candy and Turkish delight containing different carob concentrate additions in their formulation. ${ }^{\star} \mathrm{TP}=$ Total phenolic content, DPPH $=1$,1-diphenyl-2-picrylhydrazyl and FRAP $=$ Ferric reducing antioxidant power.

Table 4. Some physicochemical properties of toffee, jelly and Turkish delight containing carob concentrate.

\begin{tabular}{cccc}
\hline \multirow{2}{*}{ Property (\%) } & \multicolumn{3}{c}{ Confectionary products } \\
\cline { 2 - 4 } & Toffee $\left(5 \% \mathrm{CC}^{*}\right)$ & Jelly candy $\left(20 \% \mathrm{CC}^{*}\right)$ & Turkish delight $\left(10 \% \mathrm{CC}^{*}\right)$ \\
\hline Moisture & $14.79 \pm 0.31$ & $23.14 \pm 0.42$ & $14.80 \pm 0.14$ \\
TSS & $76.8 \pm 0.057$ & $70.3 \pm 0.056$ & $75.4 \pm 0.057$ \\
Titratable acidity & $0.31 \pm 0.04$ & $0.22 \pm 0.10$ & $0.14 \pm 0.46$ \\
Total sugars & $68.53 \pm 0.46$ & $69.53 \pm 0.44$ & $69.15 \pm 0.36$ \\
Reducing sugars & $43.26 \pm 0.20$ & $41.02 \pm 0.50$ & $40.17 \pm 0.61$ \\
Non-reducing sugars & $25.27 \pm 0.15$ & $28.51 \pm 0.10$ & $28.98 \pm 0.20$ \\
\hline
\end{tabular}

Values are mean $\pm \mathrm{SD}(\mathrm{n}=3)$. TSS $=$ Total solids. ${ }^{*} \mathrm{CC}:$ Carob concentrate. 


\subsubsection{Turkish Delight}

According to the panelist's preference, the Turkish delight product containing $10 \%$ carob concentrate was more acceptable in its appearance and odor than other prepared products including the control (Figure 3 ). The total acceptability by panelists ranged from fair to good for products free and having various levels of carob concentrate. Table 4 and Figure 4 summarized some physicochemical, polyphenols content and antioxidant activity of the products containing $10 \%$ carob concentrate. This product contained nearly $15 \%$ moisture, high value of both TSS (75.4\%) and total sugars in addition to low total acidity (0.14\%), Figure 4.

Addition 10\% of carob concentrate caused a 9.1, 6.3 and 2.4 time increase in total phenolic content, DPPH inhibition activity and FRAP, respectively. Again and as mentioned before, carob concentrate addition can improve the keeping quality, nutritional value and healthy benefits of Turkish delight product. Generally, this product had chewiness texture, an attractive transparency appearance, delicate flavor and color in lightness.

To keep such advantages, carob confectionery products should be individual wrapped in an oxygen and moisture proof films such as plain or metalized cellophane or inside glass, tin plate or carton boxes.

\section{Conclusion}

Seedless carob powder found to be rich source of sugars, calcium and polyphenols content. Therefore, it can be used to prepare healthy drinks, concentrate and confectionery products. Selection of the proper packaging materials and good storage conditions helps in keeping the healthy quality of such product for long time.

\section{Acknowledgements}

The authors are thankful to Prof. Dr. Yehia Gamal EL-Din Moharram, Prof. of Food Science and Technology, Faculty of Agric., El-Shatby, Alex. University for his support and valuable advices during carrying out the work. Also, we would like to thank Dr. Mahmoud Ibrahim El-Sayed, Department of Dairy Technology Research, Food Technology Research Institute, ARC, Giza, Egypt, for his help in carrying out and revision of this article.

\section{Conflicts of Interest}

The authors declare no conflicts of interest regarding the publication of this article.

\section{References}

[1] Dakia, P.A., Wathelet, B. and Paquot, M. (2007) Isolation and Chemical Evaluation of Carob (Ceratonia siliqua L.) Seed Germ. Food Chemistry, 102, 1368-1374. https://doi.org/10.1016/j.foodchem.2006.05.059

[2] Durazzo, A., Turfani, V., Narducci, V., Azzini, E., Maiani, G. and Carcea, M. (2014) 
Nutritional Characterisation and Bioactive Components of Commercial Carobs Flours. Food Chemistry, 153, 109-113. https://doi.org/10.1016/j.foodchem.2013.12.045

[3] Naghmouchi, S., Khouja, M.L., Romero, A., Tous, J. and Boussaid, M. (2009) Tunisian Carob (Ceratonia siliqua L.) Populations: Morphological Variability of Pods and Kernel. Scientia Horticulturae, 121, 125-130.

https://doi.org/10.1016/j.scienta.2009.02.026

[4] Tetik, N., Turhan, I., Oziyci, H.R., Gubbuk, H., Karhan, M. and Ercisli, S. (2011) Physical and Chemical Characterization of Ceratonia siliqua L. Germplasm in Turkey. Scientia Horticulturae, 129, 583-589. https://doi.org/10.1016/j.scienta.2011.04.029

[5] Ayaz, F.A., Torun, H., Ayaz, S., Correia, P.J., Alaiz, M., Sanz, C., Gruz, J. and Strnad, M. (2007) Determination of Chemical Composition of Anatolian Carob Pod (Ceratonia siliqua L.): Sugars, Amino and Organic Acids, Minerals and Phenolic Compounds. Journal of Food Quality, 30, 1040-1055. https://doi.org/10.1111/j.1745-4557.2007.00176.x

[6] Karababa, E. and Coşkuner, Y. (2013) Physical Properties of Carob Bean (Ceratonia siliqua L.): An Industrial Germ Yielding Crop. Industrial Crops and Products, 42, 440-446. https://doi.org/10.1016/j.indcrop.2012.05.006

[7] Özcan, M.M., Arslan, D. and Gökçalik, H. (2007) Some Compositional Properties and Mineral Contents of Carob (Ceratonia siliqua) Fruit, Flour and Syrup. International Journal of Food Sciences and Nutrition, 58, 652-658. https://doi.org/10.1080/09637480701395549

[8] Youssef, M.K.E., El-Manfaloty, M.M. and Ali, H.M. (2013) Assessment of Proximate Chemical Composition, Nutritional Status, Fatty Acid Composition and Phenolic Compounds of Carob (Ceratonia siliqua L.). Food and Public Health, 3 , 304-308.

[9] Kumazawa, S., Taniguchi, M., Suzuki, Y., Shimura, M., Kwon, M.-S. and Nakayama, T. (2002) Antioxidant Activity of Polyphenols in Carob Pods. Journal of Agricultural and Food Chemistry, 50, 373-377. https://doi.org/10.1021/jf010938r

[10] Scalbert, A., Manach, C., Morand, C., Rémésy, C. and Jiménez, L. (2005) Dietary Polyphenols and the Prevention of Diseases. Critical Reviews in Food Science and Nutrition, 45, 287-306. https://doi.org/10.1080/1040869059096

[11] Roseiro, L.B., Tavares, C.S., Roseiro, J.C. and Rauter, A.P. (2013) Antioxidants from Aqueous Decoction of Carob Pods Biomass (Ceretonia siliqua L.): Optimisation Using Response Surface Methodology and Phenolic Profile by Capillary Electrophoresis. Industrial Crops and Products, 44, 119-126. https://doi.org/10.1016/j.indcrop.2012.11.006

[12] El Batal, H., Hasib, A., Ouatmane, A., Dehbi, F., Jaouad, A. and Boulli, A. (2011) Sugar Composition and Yield of Syrup Production from the Pulp of Moroccan Carob Pods (Ceratonia siliqua L.). Arabian Journal of Chemistry, 153, S955-S959.

[13] Shaouli, M.C. and Fisher, Y. (1997) Nature's Wealth: Health and Healing Plants. Beit Knesset Shaouli, Ashdod.

[14] Biner, B., Gubbuk, H., Karhan, M., Aksu, M. and Pekmezci, M. (2007) Sugar Profiles of Thepods of Cultivated and Wild Types of Carob Bean (Ceratonia siliqua L.) in Turkey. Food Chemistry, 100, 1453-1455. https://doi.org/10.1016/j.foodchem.2005.11.037

[15] Bengoechea, C., Romero, A., Villanueva, A., Moreno, G., Alaiz, M., Millan, F., Guerrero, A. and Puppo, M.C. (2008) Composition and Structure of Carob (Cera- 
tonia siliqua L.) Germ Proteins. Food Chemistry, 107, 675-683. https://doi.org/10.1016/j.foodchem.2007.08.069

[16] Čepo, D.V., Mornar, A., Nigović, B., Kremer, D., Radanović, D. and Dragojević, I.V. (2014) Optimization of Roasting Conditions as an Useful Approach for Increasing Antioxidant Activity of Carob Powder. LWT-Food Science and Technology, 58, 578-586. https://doi.org/10.1016/j.lwt.2014.04.004

[17] Tsatsaragkou, K., Gounaropoulos, G. and Mandala, I. (2014) Development of Gluten Free Bread Containing Carob Flour and Resistant Starch. LWT-Food Science and Technology, 58, 124-129. https://doi.org/10.1016/j.lwt.2014.02.043

[18] Rtibi, K., Selmi, S., Grami, D., Amri, M., Eto, B., El-Benna, J., Sebai, H. and Marzouki, L. (2017) Chemical Constituents and Pharmacological Actions of Carob Pods and Leaves (Ceratonia siliqua L.) on the Gastrointestinal Tract: A Review. Biomedicine \& Pharmacotherapy, 93, 522-528. https://doi.org/10.1016/j.biopha.2017.06.088

[19] Custodio, L., Escapa, A.L., Fernandes, E., Fajardo, A., Aligue, R., Albericio, F., Neng, N., Nogueira, J.M. and Romano, A. (2011) Phytochemical Profile, Antioxidant and Cytotoxic Activities of the Carob Tree (Ceratonia siliqua L.) Germ Flour Extracts. Plant Foods for Human Nutrition, 66, 78-84. https://doi.org/10.1007/s11130-011-0214-8

[20] Owen, R.W., Haubne, R., Hull, W.E., Erben, G., Spiegelhalder, B., Bartsch, H. and Haber, B. (2003) Isolation and Structure Elucidation of the Major Individual Polyphenols in Carob Fiber. Food and Chemical Toxicology, 41, 1727-1738. https://doi.org/10.1016/S0278-6915(03)00200-X

[21] Dhaouadi, K., Belkhir, M., Akinocho, I., Raboudi, F., Pamies, D., Barrajón, E., Estevan, C. and Fattouch, S. (2014) Sucrose Supplementation during Traditional Carob Syrup Processing Affected Its Chemical Characteristics and Biological Activities. LWT-Food Science and Technology, 57, 1-8. https://doi.org/10.1016/j.lwt.2014.01.025

[22] Garcia, T. (2000) Analysis and Gelatin-Based Confections. The Manufactoring Confectioner, 80, 93-101.

[23] Charoen, R., Savedboworn, W., Phuditcharnchnakun, S. and Khuntaweetap, T. (2015) Development of Antioxidant Gummy Jelly Candy Supplemented with Psidium guajava Leaf Extract. Applied Science and Engineering Progress, 8, 145-151. https://doi.org/10.14416/j.ijast.2015.02.002

[24] Samsiah, M.S., Moey, S.W., Noor Azizah, A. and Latifah, M.S. (2009) Comparative Acceptability and Stability of Toffee Made from Powdered and Fresh Juice of $\mathrm{Mo}$ rindacitrifolia. Journal of Tropical Agriculture and Food Science, 37, 171-178.

[25] AOAC (2000) Official Methods of Analysis. 17th Edition, Association of Official Analytical Chemists, Washington DC.

[26] Singleton, V.L. and Rossi, J.A. (1965) Colorometry of Total Phenolics with Phosphomolybdic-Phosphotungstic Acid Reagents. American Journal of Enology and Vticulture, 16, 144-158.

[27] Brand-Williams, W., Cuvelier, M.E. and Berset, C. (1995) Use of Free Radical Method to Evaluate Antioxidant Activity. LWT-Food Science and Technology, 28, 25-30. https://doi.org/10.1016/S0023-6438(95)80008-5

[28] Miliauskas, G., Venskutonis, P.R. and Van Beek, T.A. (2004) Screening of Radical Scavenging Activity of Some Medicinal and Aromatic Plant Extracts. Food Chemistry, 85, 231-237. https://doi.org/10.1016/j.foodchem.2003.05.007

[29] Lim, Y.Y. and Quah, E.P.L. (2007) Antioxidant Properties of Different Cultivars of 
Portulaca oleracea. Food Chemistry, 103, 734-740. https://doi.org/10.1016/j.foodchem.2006.09.025

[30] Boublenza, I., Lazouni, H.A., Ghaffari, L., Ruiz, K., Fabiano-Tixier, A.-S. and Chemat, F. (2017) Influence of Roasting on Sensory, Antioxidant, Aromas, and Physicochemical Properties of Carob Pod Powder (Ceratonia siliqua L.). Journal of Food Quality, 2017, Article ID: 419367. https://doi.org/10.1155/2017/4193672

[31] Pulido, R., Bravo, L. and Saura-Calixto, F. (2000) Antioxidant Activity of Dietary Polyphenols as Determined by a Modified Ferric Reducing/Antioxidant Power Assay. Journal of Agricultural and Food Chemistry, 48, 3396-3402. https://doi.org/10.1021/jf9913458

[32] SAS (2004) SAS Procedure Guide "Version 6.12 Ed.”. SAS Institute Inc., Cary.

[33] Lafuente, B. (1961) Azticares de la algarroba I. La fermentaci6n selectiva de lashexosas en la obtenci6n de sacarosa. Revista de Agricultura y Technologia de Alimentos, 1, 1-7.

[34] Sahin, H., Topuz, A., Pischetsrieder, M. and Özdemir, F. (2009) Effect of Roasting Process on Phenolic, Antioxidant and Browning Properties of Carob Powder. European Food Research and Technology, 230, Article No. 155.

https://doi.org/10.1007/s00217-009-1152-7

[35] González, M.J., Torres, J.L., Medina, I. (2010) Impact of Thermal Processing on the Activity of Gallotannins and Condensed Tannins from Hamamelis virginiana Used as Functional Ingredients in Seafood. Journal of Agricultural and Food Chemistry, 58, 4274-4283. https://doi.org/10.1021/jf904032y

[36] Papagiannopoulos, M., Wollseifen, H. R., Mellenthin, A., Haber, B. and Galensa, R. (2004) Identification and Quantification of Polyphenols in Carob Fruits ( $\mathrm{Ce}$ -

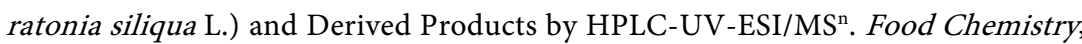
52, 3784-3791. https://doi.org/10.1021/jf030660y

[37] Klenow, S., Jahns, F., Pool Zobel, B.L. and Glei, M. (2009) Does an Extract of Carob (Ceratonia siliqua L.) Have Chemopreventive Potential Related to Oxidative Stress and Drug Metabolism in Human Colon Cells? Journal of Agricultural and Food Chemistry, 57, 2999-3004. https://doi.org/10.1021/jf802872b 